\title{
KONTRIBUSI GENRE ASSOCIATION PICTURE STORY DALAM MEMPRODUKSI WACANA KEBANGSAAN PADA FILM DOKUMENTER EPIC JAVA DAN ETANAN
}

\author{
Febriyanti Pratiwi ${ }^{1}$ \\ ${ }^{11}$ Program Studi Kajian Budaya dan Media, Sekolah Pascasarjana, \\ Universitas Gadjah Mada
}

\begin{abstract}
ABSTRAK
Tulisan ini mengkaji dua film dokumenter Indonesia dengan genre association picture story yang berjudul Epic Java (2013) karya Febrian Nurrahman dan Etanan (2018) karya Riandhani Yudha. Fokus kajian ini menganalisis bagaimana genre association picture story dalam dua film tersebut berkontribusi dalam memproduksi dan mengartikulasikan wacana kebangsaan menjadi sebuah film dokumenter non-narasi. Dengan menggunakan teori semiotika film dari Christian Metz dan multimodality dari Gunther Kress dan Theo Van Leeuwen, analisa elemen sinematografi dari film Epic Java dan Etanan menunjukkan bahwa kriteria dan bentuk dari genre association picture story mempengaruhi bagaimana narasi kebangsaan dituturkan lewat kumpulan asosiasi visual.
\end{abstract}

Kata-kata Kunci: Association Picture Story; Dokumenter; Film; Genre; Kebangsaan

\section{THE CONTRIBUTION OF ASSOCIATION PICTURE STORY PRODUCING NATIONALISM DISCOURSE IN DOCUMENTARY FILMS EPIC JAVA AND ETANAN}

\begin{abstract}
This study will identify two Indonesian documentary films which using association picture story, Epic Java (2013) directed by Febrian Nurrahman and Etanan (2018) directed by Riandhani Yudha. It will focuses on how the genre association picture story in that two films contribute at producing and articulate the idea of nationalism discourse into non-naration documentary film. Through the application of Christian Metz's film semiotics theory and Gunther Kress and Theo Van Leeuwen's multimodality discourse, the cinematography analysis of Epic Java and Etanan shows that the form of association picture story contribute at how the nationalism discourse is visualized.
\end{abstract}

Keywords: Association Picture Story; Documentary; Film; Genre; Nationalism

Korespondensi: Febriyanti Pratiwi. Sekolah Pascasarjana, Universitas Gadjah Mada. Jl. Teknika Utara, Pogung Kidul, Sinduadi, Mlati, Kabupaten Sleman, Daerah Istimewa Yogyakarta 55281.

Email: febriyantifp@gmail.com 


\section{PENDAHULUAN}

Film dokumenter adalah bentuk film dimana proses produksinya berdasar pada aspek realistik dan kenyataan informasi yang ada di lapangan. Konten film dokumenter lebih terfokus kepada subyek yang mampu memberikan wawasan baru, serta bersifat persuasif agar mampu menghasilkan sudut pandang yang berbeda. Tidak seperti kebanyakan film fiksi, dokumenter berurusan dengan fakta. Manusia atau para pelaku, tempat dan peristiwa tidak dibuat-buat. Para pembuat film dokumenter percaya mereka menciptakan dunia di dalam filmnya seperti apa adanya (Gianneti, 1995).

\section{Berbicara mengenai praktik} pendokumentasian peristiwa dan kehidupan masyarakat, film dokumenter hadir sebagai bentuk yang dinamis dan representatif. Tidak lagi hanya merekam jejak kebudayaan, namun juga mampu menggiring pembuat maupun penonton film dokumenter ke dalam perspektif tertentu dalam melihat sebuah kehidupan masyarakat. Film dokumenter kemudian berkembang melahirkan bentuk-bentuk yang beragam. Salah satu genre dari film dokumenter adalah jenis association picture story, yaitu teknik penyutradaraan film dokumenter nonnarasi dengan mengutamakan aspek visual atau gambar bergerak sebagai media untuk menyampaikan informasi keseluruhan cerita dalam film. Gaya penyutradaraan ini seringkali disebut dengan metode eksperimental yang memiliki elemen bercerita lebih kompleks dibanding jenis film narasi.

Beberapa judul film dokumenter di Indonesia yang menggunakan gaya association picture story adalah Epic Java (2013) karya Febian Nurrahman, dan Etanan (2018) karya Riandhani Yudha Pamungkas. Kedua film tersebut menceritakan tentang keberagaman masyarakat, kesuburan dan kekayaan alam Indonesia yang melimpah, bagaikan warisan para dewa dari surga yang diturunkan dalam bentuk bumi khatulistiwa, dan bagaimana masyarakat melebur menjadi bagian dari keberagaman tersebut. Keunikan dan ciri khas dari film Epic Java dan Etanan terletak pada visualisasi tentang identitas multikultural Indonesia, yang disajikan dengan sudut pandang, pergerakan dan teknologi gambar yang tidak biasa ditangkap oleh mata manusia secara langsung. Obyek gambar yang dipilih di kedua film tersebut tentu merunut pada kategori konten yang menceritakan tentang kekayaan bangsa seperti taman nasional, situs-situs bersejarah, upacara adat, serta kondisi sosialekonomi masyarakat. Lapisan informasi tentang identitas kebangsaan yang begitu kompleks dan padat seolah mampu diartikulasikan dengan gamblang dalam bentuk film dokumenter association picture story. 


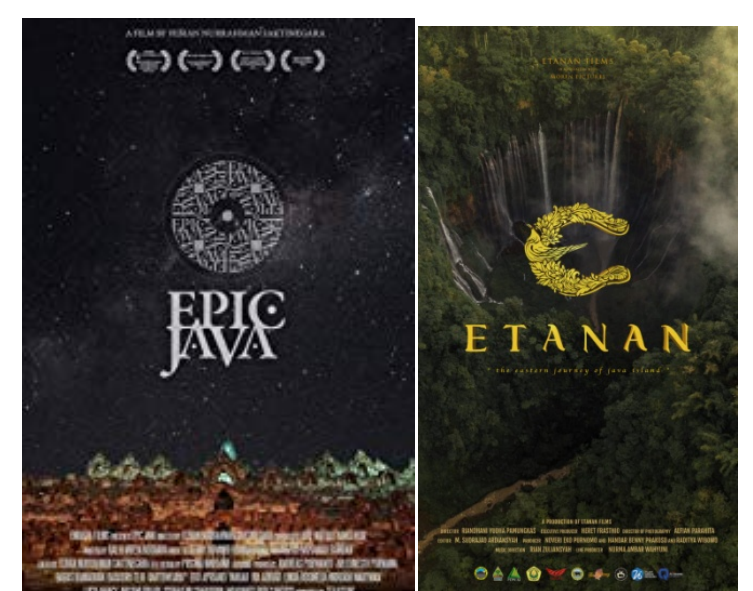

Gambar 1. Poster film Epic Java dan Etanan.

Kedua film ini pun terbukti mampu menggambarkan kebudayaan Indonesia lewat cara bertutur yang berbeda, hingga mampu mendapat apresiasi yang luar biasa baik di dalam maupun luar negeri. Beberapa penghargaan yang berhasil diraih oleh film Epic Java antara lain; Penghargaan Khusus Film Dokumenter Piala Maya 2013, Penghargaan Khusus Film Dokumenter Pendek Festival Film Indonesia (FFI) 2013, Best Documentary 2nd SBM Golden Lens International Documentary Festival, Official Selection Festival Film Dokumenter Bali (FFDB) 2012, Most Inspiring Share dalam Inspire Video Competition PPI United Kingdom 2012, Best Trailer \& Best Camera DOCDAYS Film Festival di Universitas Indonesia 2012, The Best Trailer and The Best Cinematography pada Documentary Days 2012. Dan penghargaan yang berhasil diraih oleh film Etanan yakni Film Terbaik Denpasar Film Festival 2018, dan Film Rekomendasi Juri Sinematografi Terbaik Festival Dokumenter Budi Luhur 2018.

Banyaknya penghargaan serta apresiasi yang didapat oleh kedua film dokumenter tersebut membuktikan bahwa cara bertutur visual non-narasi mampu menyampaikan pesan dengan bahasa yang universal, yakni bahasa gambar. Asosiasi visual yang disusun juga dapat menjangkau segmentasi penonton yang lebih luas, misalnya penonton yang tidak mengenal alam dan kebudayaan Indonesia sekalipun. Genre association picture story pun akhirnya memiliki nyawa tersendiri dalam menyampaikan pesan yang ada dalam film.

Karakter utama film dokumenter dengan gaya association picture story adalah kekuatan untuk menghasilkan persepsi dan makna baru dari keterkaitan antara satu gambar dengan gambar yang lain. Bentuk association picture story dalam perfilman Indonesia masih tergolong sedikit dan cenderung memiliki target produksi, distribusi dan penonton yang lebih terbatas. Hal ini disebabkan oleh film association picture story memiliki batas-batas sinematografi yang berbeda dari jenis film lainnya, karena hanya mengandalkan visual tanpa narasi. Genre association picture story justru muncul di perfilman Indonesia sebagai alat untuk mengeksploitasi citra yang menggambarkan secara kompleks tentang kekayaan alam dan keberagaman masyarakat yang identik dengan multikultural di Indonesia. Ada kecenderungan bahwa genre association picture story di Indonesia masih terbatas pada sajian informasi yang mengutamakan kualitas serta otentisitas visual sebagai pengganti narasi verbal atau tekstual yang hilang.

Permasalahan utama yang muncul ketika hendak menganalisa sebuah film dokumenter adalah apakah bentuk dan jenis film dokumenter mempunyai andil dalam mengkonstruksi konten film, ketika prinsip 
utama film dokumenter adalah merekam fakta tanpa dibuat-buat? Sementara film dokumenter masih memiliki turunan genre yang bervariasi tergantung bagaimana sudut pandang dan konteks informasi yang akan disampaikan pembuatnya. Gaya penyutradaraan association picture story pun hadir sebagai salah satu moda yang memungkinkan bagaimana data gambar dihadirkan secara lugas, dengan asumsi bahwa genre association picture story membebaskan pembuat film dari tuduhan membentuk opini pribadi dalam narasi film yang terlalui menggurui, karena penonton dibebaskan untuk memberi makna terhadap film tersebut. Kendati demikian, proses pembuatan karya film dokumenter dengan gaya association picture story tetap berdasar pada riset dan data yang valid untuk mendukung konten film, dan tentu berangkat dari tujuan dan wacana apa yang hendak disampaikan oleh pembuat film.

Kajian ini terfokus pada aplikasi genre association picture story dalam film dokumenter Epic Java (2013) dan Etanan (2018). Dengan menggunakan metode analisis multimodality dari Gunther Kress dan Theo Van Leeuwen, kajian pemilihan citra bergerak yang ditampilkan dari kedua film tersebut menunjukkan adanya narasi tentang wacana kebangsaan yang dibentuk berdasarkan kumpulan gambar non-narasi, serta gabungan dari beberapa skema visual tidak beraturan. Informasi dalam kedua film tersebut dibangun dengan aspek visual non-narasi, sebuah komunikasi yang menuntut komunikannya untuk dapat membaca setiap citra yang dimunculkan. Genre association picture story merupakan salah satu moda komunikasi yang dipilih oleh pembuat film, sebagai bentuk yang diyakini mampu mengekspresikan keseluruhan pesan dalam film. Tahapan membangun makna lewat strata produksi dari Gunther Kress dan Theo Van Leeuwen menjadi dasar kajian ini dalam membongkar produksi wacana kebangsaan dalam film Epic Java dan Etanan, yang disampaikan dengan menggunakan gaya penyutradaraan association picture story.

Apabila genre association picture story memiliki spesifikasi yang ketat terhadap narasi film yang hanya disajikan dalam format visual, lalu bagaimana konstruksi wacana kebangsaan dalam film dokumenter Epic Java dan Etanan diartikulasikan menjadi visualisasi non-narasi? Pemilihan obyek visual dalam kedua film tersebut menjadi fondasi penting untuk membangun cara pandang penonton dalam mengidentifikasi asosiasi visual film. Genre association picture story pun memiliki peran yang besar dalam mendesain konten film dokumenter Epic Java dan Etanan. Artikulasi ideologi nasionalisme Indonesia lewat sumber daya visual yang mampu membangun narasi baru tentang nilai-nilai kebangsaan.

\section{TINJAUAN PUSTAKA}

Penelitian film dokumenter dengan pengkajian genre dan sinematografi masih tergolong sedikit. Penelitian terdahulu tentang film dokumenter sebagian besar masih terfokus 
pada studi resepsi dan studi komunikasi yang mempermasalahkan bagaimana film dokumenter mampu menyampaikan sebuah konten dengan opini yang bisa diterima dan mempengaruhi penonton secara luas. Namun penelitian yang menjelaskan dengan genre apa dan bagaimana penyampaian melalui teknik sinematografi masih minim. Walaupun sesungguhnya bentuk pesan dalam sebuah film dokumenter ditentukan pada bagaimana citra itu 'dikemas' menggunakan teknik-teknik sinematografi.

Salah satu kajian akademik yang pernah meneliti film Epic Java adalah penelitian milik Muhammad Aditya (2015) yang berjudul 'Pengaruh Film Epic Java Terhadap Minat Wisata Komunitas CUT Film di Bandung'. Kajian Aditya fokus pada penelitian statistik tentang bagaimana film dokumenter Epic Java mempengaruhi minat penontonnya dalam melakukan perjalanan wisata ke tempat-tempat yang menjadi lokasi pengambilan gambar dari film Epic Java.

Berbeda dengan penelitian di atas yang meneliti tentang studi resepsi audiens terhadap film dokumenter, artikel Iwan Setiawan (2017) yang berjudul 'Dokumenter TV: “Udjo \& Saung Angklung” sebagai Manifestasi Budaya Sunda' (Setiawan, 2017) membicarakan tentang proses produksi sebuah film dokumenter untuk televisi. Namun Iwan Setiawan kurang mengeksplor bagaimana bentuk film dokumenter itu mampu menarasikan ide tentang manifestasi budaya Sunda. Penelitian ini masih terlalu terfokus pada konten dan mengesampingkan teknik bertutur dalam film dokumenter. Berdasar pada minimnya penelitian tentang bentuk-bentuk dan genre dari film dokumenter, maka kajian ini akan menganalisa genre dari film dokumenter sebagai alat untuk mengemas narasi dalam film.

\section{METODE PENELITIAN}

Kajian ini menggunakan dua film dokumenter bergenre association picture story, yakni film Epic Java (2013) yang disutradarai oleh Febrian Nurrahman, dari rumah produksi Embara Films. Serta film Etanan (2018) yang disutradarai oleh Riandhani Yudha, di bawah naungan rumah produksi Etanan Films. Data visual yang dianalisis akan diambil dari penggalan gambar dari kedua film tersebut.

Tabel 1. Aspek material film Epic Java dan Etanan.

\begin{tabular}{|c|c|c|}
\hline Judul & Epic Java & Etanan \\
\hline Sutradara & $\begin{array}{c}\text { Febrian } \\
\text { Nurrahman }\end{array}$ & $\begin{array}{c}\text { Riandhani } \\
\text { Yudha }\end{array}$ \\
\hline Produksi & $\begin{array}{c}\text { Embara } \\
\text { Films } \\
(2013)\end{array}$ & $\begin{array}{c}\text { Etanan Films } \\
(2018)\end{array}$ \\
\hline Durasi & 24 menit & 45 menit \\
\hline $\begin{array}{l}\text { Lingkup } \\
\text { narasi }\end{array}$ & Pulau Jawa & $\begin{array}{c}\text { Wilayah Tapal } \\
\text { Kuda }\end{array}$ \\
\hline $\begin{array}{l}\text { Narasi } \\
\text { verbal }\end{array}$ & $\begin{array}{c}\text { Prolog \& } \\
\text { Epilog }\end{array}$ & - \\
\hline $\begin{array}{l}\text { Premis } \\
\text { narasi }\end{array}$ & $\begin{array}{c}\text { Lahirnya } \\
\text { tanah Jawa } \\
\text { dan } \\
\text { kemegahan } \\
\text { alamnya. }\end{array}$ & $\begin{array}{c}\text { Potensi sumber } \\
\text { daya alam } \\
\text { wilayah Tapal } \\
\text { Kuda yang } \\
\text { melimpah, } \\
\text { namun terdapat } \\
\text { ketimpangan }\end{array}$ \\
\hline
\end{tabular}




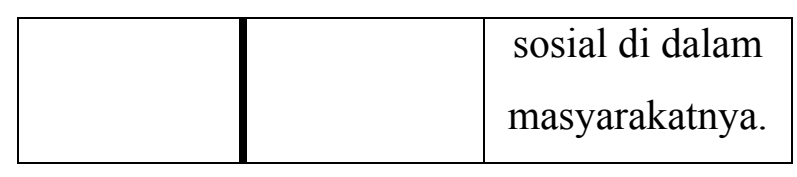

Analisis wacana dalam film dokumenter Epic Java dan Etanan kemudian berangkat dari bagaimana genre association picture story mampu mengartikulasikan data dan sumber daya citra bergerak menjadi skema visual yang melahirkan narasi baru tentang identitas wilayah dalam konteks kebangsaan. Penelitian genre association picture story meliputi analisis skema visual dengan kriteria type of shots, sudut pengambilan gambar, serta penyuntingan gambar yang menjadi kekhasan genre tersebut.

Ketiga aspek ini sebagai landasan membentuk lapisan makna dalam film dokumenter association picture story.

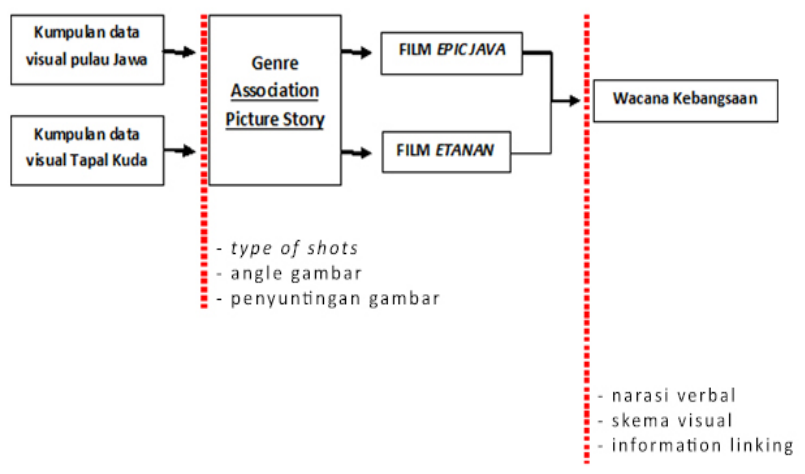

Gambar 2. Kerangka penelitian

Dengan menggolongkan karakter visual dari masing-masing film dokumenter Epic Java dan Etanan, akan ditemukan beragam moda komunikasi yang digunakan untuk menyampaikan narasi besar atau pesan dalam film. Adanya narasi verbal yang menjadi pembuka dan penutup dalam Epic Java, skema pembabakan visual association picture story dari kedua film, serta informasi yang menghubungkan narasi visual dari kedua film tersebut dengan wacana kebangsaan. Kajian ini berdasar pada konsep semiotika film dari Christian Metz untuk menganalisis teknis citra bergerak yang digunakan film Epic Java dan Etanan, serta konsep multimodalitas dari Gunther Kress dan Theo Van Leeuwen sebagai metode untuk membaca konfigurasi gambar dalam film yang membangun nilai-nilai nasionalisme dan ideologi kebangsaan.

\section{HASIL DAN PEMBAHASAN}

Film Dokumenter Association Picture Story

Narasi tidak hanya dibangun dengan tuturan atau dialog langsung, namun juga dapat disampaikan dengan menunjukkan sesuatu atau gambar yang mampu bercerita (Gaut, 2010). Kriteria serta ciri khas yang ada dalam film dokumenter jenis association picture story didasarkan pada prinsip utamanya, yakni visual non-narasi. Prinsip tersebut tentunya akan membentuk bagaimana tahapan produksi gambar. Dimulai dari estetika visual, efektifitas pengambilan gambar, efisiensi informasi gambar, limitasi frame, dan memaksimalkan kesinambungan aspek antar gambar sehingga mampu menghasilkan informasi yang diinginkan. Batasan-batasan visual dengan gaya association picture story akan berimbas pada konten visual yang dipilih. Pemadatan informasi dalam film jenis ini pun menjadi lebih selektif dan ketat untuk bisa menjelaskan cerita dari gambar yang sudah tersusun menjadi keseluruhan film. 
Bentuk bertutur film association picture story mengacu pada pembagian skema pembabakan visual sehingga mampu menghasilkan informasi dan simbol-simbol yang dipaparkan secara visual. Ada susunan gambar yang seragam, namun juga banyak susunan gambar yang sengaja dikontraskan untuk menghasilkan makna yang paradoks. Perbandingan visual serta oposisi biner sekuens menjadi kekhasan visual dari film dokumenter gaya association picture story.

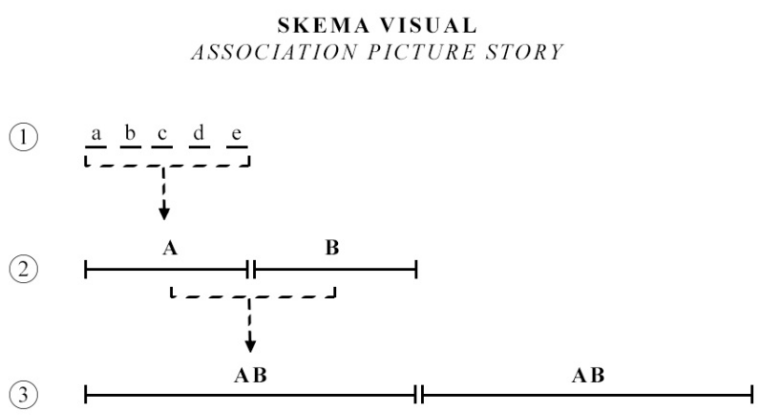

Gambar 3. Skema pembabakan visual

Konfigurasi penyusunan skema visual dalam film dokumenter association picture story memiliki dasar dari kumpulan gambar bergerak yang tidak beraturan, namun melahirkan makna apabila dirangkai menjadi sebuah sekuens atau asosiasi gambar yang dilihat secara sebagian atau keseluruhan. Rangkaian dasar skema visual dalam film association picture story dapat dilihat di Gambar 1. Gambar tak beraturan seperti a-b-cd-e menjadi sekuens A yang menghasilkan sebagian informasi dari film, digabungkan dengan gambar tak beraturan lainnya dari sekuens B, lalu menyajikan makna dan informasi baru dalam sekuens $\mathrm{AB}$, begitu seterusnya hingga menjadi sebuah film utuh. Kemampuan bertutur film association picture story menjadi sangat bergantung pada asosiasi gambar yang dipilih apakah bisa menghadirkan makna informasi yang sesuai dengan tujuan film tersebut.

Genre association picture story merupakan material untuk memproduksi wacana-wacana yang hendak dihadirkan dalam film dokumenter. Dengan segala bentuk materialnya, seluruh obyek gambar yang diambil akan diolah sedemikian rupa sesuai karakter dari association picture story, untuk kemudian menjadi sebuah situs atau teks film dimana macam-macam moda yang didapat mampu diartikulasikan dengan lugas dan sesuai dengan misi pembuat film. Gaya film eksperimental seperti ini sarat dengan lapisan makna yang ikut dibangun guna mengekspresikan dinamika cerita hingga konklusi narasi yang umumnya berisi pesan utama dari sebuah film. Untuk dapat memberikan pesan yang menjadi misi pembuat film, genre association picture story memiliki caranya sendiri dalam bertutur.

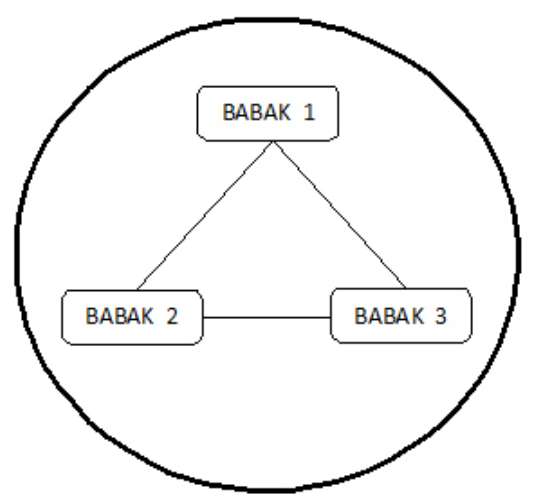

Gambar 4. Struktur naratif association picture story

Berbeda dengan jenis film bernarasi linier yang pada umumnya terbagi menjadi pembabakan cerita dengan dinamika yang semakin memuncak, babak narasi dalam konten 
association picture story terikat satu sama lain membentuk asosiasi yang masing-masing pembabakannya tidak dapat terpisah dan saling menunjang makna dari keseluruhan film. Seperti yang terlihat di Gambar 2, keutuhan sebuah film association picture story bergantung pada seberapa kuat ikatan antar babak narasi visual, sehingga mampu membentuk hubungan sebab-akibat secara holistik. Kombinasi banyak citra di babak 1 akan menarasikan topik tertentu yang akan didukung oleh konten di babak 2, dan babak 3 sebagai anti-tesis dari kedua babak awal atau justru menyajikan data visual berbeda yang menjadikannya paradoks. Namun ketiga babak tersebut memiliki benang merah yang apabila berhasil berkaitan satu sama lain, akan membangun sebuah wacana yang sama sekali baru. Penyusunan narasi visual ini sangatlah penting sebagai landasan narasi yang akan dibangun di keseluruhan film association picture story.

Kajian ini akan meneliti bentuk-bentuk khas dari film association picture story sebagai material untuk membangun wacana dalam konten film. Terdiri dari type of shots, sudut pengambilan gambar, dan penyuntingan gambar. Pada film Epic Java dan Etanan, keduanya memiliki karakteristik teknis yang hampir sama, namun yang menjadi faktor pembeda adalah bagaimana keempat aspek film association picture story di atas digunakan sebagai alat untuk melahirkan wacana tentang ideologi kebangsaan dalam masing-masing film.

Melalui komposisi gambar, kita dapat mengarahkan penonton kemana dan apa yang harus dilihat, serta dengan runtutan seperti apa kita harus melihat gambar tersebut (Brown, 2012). Komposisi gambar dalam frame menentukan detail informasi apa saja yang hadir dalam obyek visual. Dalam film dokumenter Epic Java dan Etanan, type of shots memiliki peran penting dalam membantuk narasi dari visual yang disajikan. Pemilihan komposisi serta obyek visual akan menghasilkan susunan informasi yang saling berkaitan.

Tabel 2. Komposisi gambar film Epic Java dan Etanan.

\begin{tabular}{|l|c|c|}
\hline Type of shots & Epic Java & Etanan \\
\hline Extreme long shot & & \\
& & \\
& &
\end{tabular}




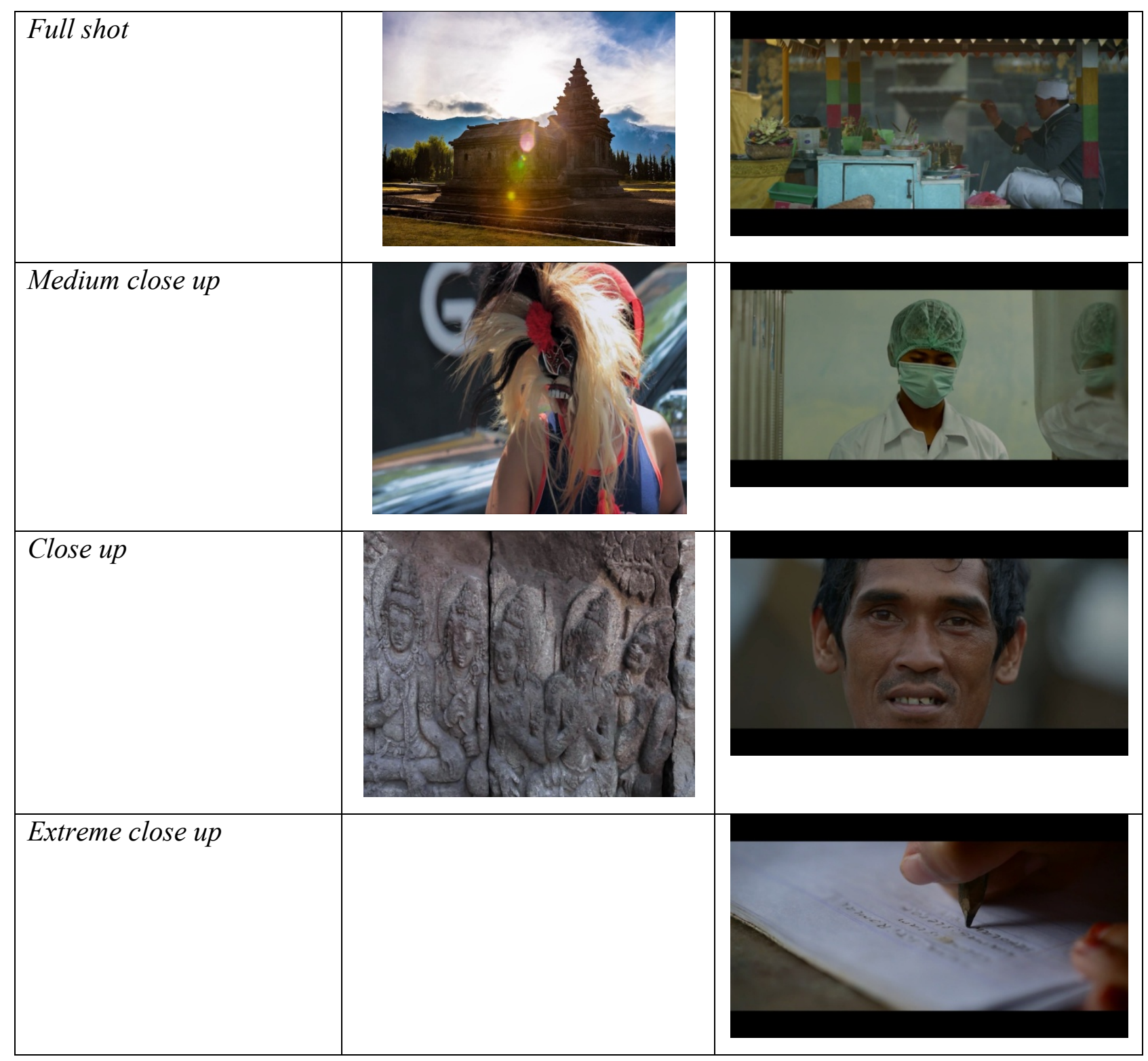

Dalam film Epic Java dan Etanan, tiap elemen shot memiliki fokus narasinya masingmasing. Extreme long shot digunakan untuk visual lanskap alam yang memang hanya memungkinkan untuk ditangkap apabila jarak pengambilan gambar cukup jauh. Selain untuk menangkap lanskap bentangan alam yang luas, gambar extreme long shot menghadirkan kesan objek yang masif dan besar. Penyajian visual seperti ini dapat menyampaikan informasi tentang bagaimana kemegahan dan keindahan alam yang dimiliki oleh bangsa ini.
Full shot dipilih untuk membingkai gambar situs-situs sejarah dan budaya yang ada di Pulau Jawa dan wilayah Tapal Kuda. Seperti candi, tempat ibadah, upacara adat dan keagamaan, serta tari-tarian atau berbagai acara kebudayaan lainnya. Untuk informasi gambar yang lebih detail, komposisi medium close up dan close up digunakan sebagai variasi komposisi untuk penegasan narasi dalam visual yang disajikan. Sedangkan extreme close up menjadi komposisi gambar yang diaplikasikan ketika ada pengerucutan fokus informasi visual. 
Genre association picture story menggunakan komposisi gambar sebagai pembentuk dinamika cerita yang disampaikan melalui kumpulan asosiasi visual. Semakin bervariasi jenis visual dan jenis komposisi yang digunakan, maka akan memproduksi narasi yang semakin kompleks dengan informasi yang padat. Selain komposisi, sudut pengambilan gambar juga memiliki peran untuk membentuk makna dalam setiap gambar yang muncul dalam film association picture story. Apabila masingmasing gambar di dalam film genre association picture story tidak memiliki motivasi dalam setiap komposisi dan sudut pengambilan gambarnya, tentu saja konten dari film association picture story hanyalah kumpulan visual tak beraturan dan tak memiliki makna secara keseluruhan.

Dan Ablan dalam bukunya yang berjudul Digital Cinematography and Directing (2002), menyatakan bahwa sudut pengambilan gambar dalam sebuah film akan menguatkan interaksi penonton ketika menyelami setiap adegan dan informasi cerita. Macam-macam sudut pengambilan gambar yakni top angle, bird's eye view, high angle, eye level, low angle, bottom view (Ablan, 2002). Sama seperti elemen sebelumnya, sudut pengambilan gambar dalam film Epic Java dan Etanan memiliki memunculkan motivasi visual dari masingmasing gambar. Visualisasi tentang gunung dan alam sekitarnya di ambil dengan sudut top, bird's eye view, serta high angle. Ketiga sudut gambar ini diambil dari posisi atas obyek untuk memaksimalkan jarak pandang dalam menangkap gambar. Sedangkan eye level dipakai untuk mengambil gambar dengan posisi sejajar mata manusia atau sejajar kamera. Eye level digunakan untuk membentuk informasi gambar yang bersifat deskriptif dan menjelaskan obyek secara gamblang. Sudut pengambilan gambar eye level dalam film Epic Java dan Etanan biasanya digunakan untuk menggambarkan visualisasi tentang kegiatan kebudayaan; seperti tari-tarian, upacara keagamaan atau parade budaya. Low angle atau bug's eye view merupakan sudut gambar yang diambil dari bawah, sehingga menyebabkan obyek dalam gambar terlihat lebih besar dari aslinya. low angle seringnya dipakai untuk memberikan efek intimidatif bagi penonton. Dan yang terakhir adalah bottom level. Kebalikan dari top angle, bottom angle adalah sudut pengambilan gambar dari bawah obyek. Dalam kedua film tersebut, bottom angle digunakan untuk mengambil gambar timelapse dari gugusan bintang di langit.

Penyuntingan gambar atau proses editing adalah proses pascaproduksi yang berperan untuk 'menjahit' kumpulan gambar hingga menjadi sebuah satu-kesatuan asosiasi visual yang utuh. Dalam film Epic Java dan Etanan, penyusunan gambar didasarkan pada skematik visual dari masing-masing pembabakan narasi. Tidak hanya menyusun gambar, namun proses editing juga memiliki andil yang besar dalam mengemas bentuk akhir film. Di kedua film tersebut, interpretasi dan 
koneksi antara satu gambar ke gambar lain, dan satu babak ke babak berikutnya sangat bergantung pada bagaimana keselarasan data gambar di meja editing. Selain itu, ritme visual dan kesinambungan audio juga penting untuk membentuk dramatik cerita. Percepatan gambar seperti teknik timelapse, hyperlapse, atau slowmotion, diperlukan untuk menghadirkan efek dramatis. Pemilihan tone warna pada film juga menghadirkan rasa tersendiri dalam memaknai setiap bagian visualnya.

Pakar sintagmatik film Christian Metz dalam buku New Vocabularies in Film Semiotics (2005) oleh Robert Stam menyatakan bahwa sebagian besar film naratif membentuk sebuah representasi berdasar pada sintagmatik, dengan unit-unit yang menggabungkan aspek ruang dan waktu dalam kombinasi yang bervariasi. Film memilih serta mengkombinasikan gambar dan suara ke bentuk sintagma, dimana elemennya saling berinteraksi (Stam, 2005). Aspek sintagmatik dalam film memungkinkan untuk menganalisa bagaimana data gambar disusun menjadi kesatuan pola yang akhirnya membentuk narasi film secara utuh.

Dalam teori sintagmatik film Metz, dijelaskan ada delapan tipe sintagmatik film, yakni autonomous shot, parallel syntagma, bracket syntagma, descriptive syntagma, alternating syntagma, scene, episodic sequence, ordinary sequence. Penelitian ini akan mengkaji penggunaan teori sintagmatik dalam film Epic Java dan Etanan. Keduanya mengaplikasikan tipe sintagmatik film yang berbeda. Epic Java menggunakan bracket syntagma, sedangkan Etanan menggunakan parallel syntagma.

Bracket syntagma adalah kesatuan narasi gambar dalam film yang tidak tersusun secara kronologis, tidak menunjukkan adanya perbandingan gambar satu dengan yang lain. Bracket syntagma juga tidak mempunyai informasi ruang dan waktu yang tegas. Dalam film Epic Java, bracket syntagma diaplikasikan dengan skema visual tanpa kronologis waktu dan peristiwa, serta tidak ada perbandingan motif visual antara satu gambar dengan gambar berikutnya. Setiap skema visual mewakili plot di tiap-tiap pembabakan narasinya secara tematik, yakni identitas Pulau Jawa. Dimulai dari hamparan gunung, perbukitan dan daerah wisata yang menjadi ikon pariwisata di masingmasing daerah di Pulau Jawa, hingga bermacam upacara keagamaan atau acara kebudayaan yang menjadi identitas dari kultur masyarakat Jawa. Semuanya dinarasikan dengan satu konsep besar tentang multikultural dalam masyarakat Jawa. Teknik bracket syntagma dalam film Epic Java dapat mengerucutkan dan menguatkan tema narasi besar di dalamnya yakni identitas wilayah dan masyarakat di Pulau Jawa. Setiap gambar dan sekuens yang disajikan akan semakin memperkuat narasi yang disampaikan dalam film Epic Java.

Hampir sama dengan bracket syntagma, parallel syntagma juga memiliki kriteria untuk membangun narasi dalam film berdasar pada bagaimana susunan gambar yang tidak memiliki kronologis ruang dan waktu mampu menunjukkan sebuah ide besar atau tematik yang akan disajikan. Perbedaannya dengan 
bracket syntagma adalah bahwa parallel syntagma memiliki aspek perbandingan oposisi dari satu gambar ke gambar lain. Misal kayamiskin, desa-kota, alami-industri, dan sebagainya. Film Etanan memiliki bentuk narasi oposisi yang menjadi satu isu yang diangkat oleh sutradara, yaitu bagaimana ketimpangan sosial yang terjadi di wilayah Tapal Kuda. Babak pertama yang menceritakan tentang sumber daya alam di Tapal Kuda yang begitu melimpah, hingga mampu menjadi rumah bagi banyak ekosistem mahluk hidup, lalu di babak berikutnya menyajikan gambaran pertumbuhan industri yang begitu pesat di beberapa daerah, dan di babak akhir, disajikan kekontrasan antara kelimpahan sumber daya alam, keragaman budaya dan identitas masyarakat Tapal Kuda yang harus bersaing dan bertahan di tengah industrialisasi yang semakin berkembang cepat. Kemudian gambaran tentang bagaimana sektor pendidikan tidak merata di semua daerah. Di babak terakhir film Etanan juga ditunjukkan tentang akses pendidikan yang masih jauh dari layak. Sedangkan industrialisasi semakin banyak dan besar. Perbandingan atau oposisi yang ada di dalam film Etanan ini menunjukkan bahwa parallel syntagma bisa digunakan sebagai teknik perbandingan dalam menyajikan informasi yang memiliki sebab-akibat atau yang bertolak-belakang.

\section{Narasi Kebangsaan dalam Epic Java dan Etanan}

Film dokumenter Epic Java dan Etanan hadir sebagai bentuk narasi kebangsaan yang mewakili nilai-nilai hidup berbangsa di tanah Indonesia. Keduanya merupakan gambaran dari prototipe semangat persatuan yang dilambangkan dengan berbagai interaksi lapisan masyarakat yang hidup berdampingan dan bergantung pada beragam kekayaan alam. Film dokumenter Epic Java dan Etanan pun mampu membingkai wajah keberagaman Indonesia melalui visualisasi yang jujur.

Untuk menganalisis menggunakan aspek multimodalitas, hal pertama yang harus diperhatikan adalah mengkaji transformasi realitas ke dalam wacana, dan bagaimana wacana itu direalisasikan dengan menggunakan beragam moda semiotik yang berbeda dalam konteks tertentu (Noviani, 2018). Type of shots, sudut pengambilan gambar, serta proses penyuntingan akan memberikan dan membentuk makna dalam keseluruhan film association picture story yang hanya bertutur menggunakan kumpulan gambar. Dari kedua film dokumenter Epic Java dan Etanan, wacana kebangsaan dibentuk dengan film non-narasi yang memiliki banyak kesamaan dalam membicarakan elemen tentang kebangsaan.

Dari segi judul, film dokumenter Epic Java dan Etanan memiliki diksi kata yang merujuk pada spesifikasi area atau wilayah yang menjadi obyek utama. Judul Epic Java menggunakan kata Bahasa Inggris Java yang 
berarti Jawa atau Pulau Jawa dalam Bahasa Indonesia, dan Etanan yang berasal dari Bahasa Jawa wetan yang berarti timur, mengacu pada lokasi wilayah Tapal Kuda yang berada di timur provinsi Jawa Timur.

Berbicara mengenai komposisi narasi atau pembabakan cerita dalam film dokumenter Epic Java dan Etanan, ada beberapa kesamaan skema visual ketika menyajikan konten tentang ke-Indonesia-an menjadi visualisasi dalam film, yaitu hamparan alam luas (didominasi oleh gunung-gunung dan perbukitan), laut dan garis pantai, flora fauna, upacara keagamaan, dan acara kebudayaan. Visualisasi gunung dan perbukitan menggambarkan wilayah geografis Indonesia yang terletak pada cincin api memiliki banyak gunung vulkanik yang masih aktif. Laut dan garis pantai menunjukkan bagaimana Indonesia sebagai negara maritim yang memiliki perairan luas dan indah. Flora fauna yang tersebar di beberapa taman nasional sering sebagai ikon tentang Indonesia sebagai rumah dari beberapa satwa langka eksotis yang dilindungi. Upacara keagamaan dan acara kebudayaan sebagai artikulasi tentang multikultural masyarakat Indonesia yang memeluk agama dan menganut kebudayaan berbeda-beda.

Narasi kebangsaan dalam produk audio visual terutama film menjadi menarik ketika identitas sebuah bangsa ditunjukkan dengan realitas elemen fisik negara sebagai keunggulan agar diketahui dan dipertahankan oleh masyarakatnya. Realitas geografis Indonesia inilah yang dipercaya sebagai identitas bangsa yang utama. Bentuk realitas adalah apa-apa yang bisa ditangkap oleh mata, yang dipercaya oleh suatu komunitas di dalamnya (Kress \& Leeuwen, 2006). Nilai-nilai kebangsaan ini yang dalam film Epic Java dan Etanan disajikan dengan sudut pandang berbeda. Dengan menggunakan aspek genre association picture story, visualisasi kebangsaan menghadirkan makna yang lebih luas dari sekadar wilayah geografis sebuah negara.

Film Epic Java menceritakan tentang daratan Pulau Jawa yang memiliki kesuburan alam melimpah, dengan beragam kultur masyarakatnya yang hidup berdampingan untuk kelestarian tanah Jawa. Sedikit berbeda dengan karakter genre association picture story yang bertutur menggunakan visual non-narasi, film Epic Java memiliki sepenggal prolog dan epilog atau kalimat pembuka dan penutup di awal film. Narasi pembuka dan penutup ini sebagai rumusan dimana dan bagaimana film ini akan menuturkan ceritanya.

Cahaya baru di bawah semesta mengawali keberadaannya.

Sebuah tempat dimana langit dan bumi saling bercengkrama.

Ketika sang surya mulai bersinar, terlihatlah sebuah daratan.

Daratan yang dahulu terombangambing di luasnya samudera, kini terpaku oleh deretan gunung-gunung di sepanjangnya.

Daratan yang sebelumnya kering dan tandus, kini dianugerahi air dan kesuburan melimpah.

Lembah-lembah hijau yang indah menghiasi seluruh daratannya.

Keindahannya menarik perhatian Dewa-Dewa untuk turun dari langit.

Turun dalam bentuk ajaran dan keyakinan.

Keyakinan tentang keberadaan semesta oleh Sang Pencipta. 
Daratan ini disebut juga sebagai Javadvipa.

(Prolog film Epic Java) (Saktinegara, 2013)

Kutipan di atas adalah kalimat pembuka dari film Epic Java. Narasi tersebut muncul sebagai pengantar untuk memberi petunjuk sekilas kepada penonton tentang konten yang akan disampaikan dalam film Epic Java. Keseluruhan kalimat pembuka mengindikasikan batasan ruang dan waktu yang akan divisualisasikan dalam film. Sebagai kalimat pembuka, tentunya kutipan di atas menjadi patokan bagaimana awal mula alur narasi film Epic Java. Dengan kata kunci 'mengawali keberadaannya', menjadi keterangan tentang permulaan lahirnya kehidupan sebuah daratan yang begitu indah dan melimpah. Juga dijelaskan adanya gununggunung yang mengelilingi, dianugerahi air, dan lembah hijau. Kata 'hijau' merujuk pada makna kemurnian alam, yang belum tersentuh oleh tangan-tangan manusia. Hal yang menarik adalah dalam kalimat pembuka di atas ada kecenderungan satu sudut pandang sebagai pihak yang menuturkan narasi film, yakni Dewa-Dewa. Pada kalimat ketujuh hingga kesembilan, menyatakan bahwa Dewa-Dewa turun dari langit karena tertarik dengan keindahan sebuah daratan yang subur, yang turun memulai perjalanan ke setiap sudut daratan itu mewujud dalam ajaran dan keyakinan. Daratan yang disebut Javadvipa, istilah kuno untuk pulau Jawa. Prolog atau kalimat pembuka dari film Epic Java tersebut sebagai penanda awal mula 'perjalanan' film ini menjelajahi kesuburan tanah Jawa.

Setelah dibuka dengan prolog di awal film, maka film Epic Java pun diakhiri dengan sepenggal epilog sebagai narasi penutup

Masa demi masa sudah terlewati.

Ribuan kali matahari terbit dan terbenam menjadi saksi perjalanan Javadvipa. langit.

Kini para Dewa sudah kembali ke

Menitipkan warisan-Nya kepada manusia agar dapat lebih memahami semesta dan isinya.

Sebagai titipan untuk peradaban selanjutnya di masa depan.

(Epilog film Epic Java)

Film Epic Java sejatinya merupakan film dokumenter yang merangkum dalam bentuk visual non-narasi tentang bagaimana jejak peradaban dan kebudayaan manusia di tanah Jawa berdampingan dengan alam yang begitu subur. Penggalan kalimat penutup diawali dengan 'Masa demi masa sudah terlewati', menandakan bagaimana film Epic Java mampu menggambarkan dan mewakili peta peradaban di tanah Jawa selama kurun waktu yang begitu lama dengan keterangan kata 'Ribuan kali matahari terbit dan terbenam'. Dua kalimat awal menunjukkan adanya keterangan rentang waktu dari narasi film Epic Java, yakni dari awal mula lahirnya daratan pulau Jawa, hingga beribu hari berikutnya dimana peradaban manusia dengan alamnya mulai tumbuh dan mengisi kehidupan di tanah Jawa. Pemilihan sumber data visual tentunya merujuk pada ruang dan waktu yang akan digunakan dalam film. Dalam film Epic Java yang 
mengisahkan tentang kelahiran peradaban di Jawa, citra yang disuguhkan pun disesuaikan dengan bagaimana simbol keutuhan dan kemegahan alam Jawa mampu membangun kehidupan manusia di sekitarnya. Pada tiga kalimat terakhir epilog, lagi-lagi sudut pandang 'Dewa' digunakan sebagai patokan narasi film. diawali dengan Dewa-dewa yang turun dari langit (dalam prolog), dan perjalanan ditutup ketika Dewa kembali ke langit. Kalimat 'Menitipkan warisan-Nya kepada manusia' membuat narasi dalam Epic Java dibangun dengan asumsi bahwa tanah Jawa adalah warisan Dewa, dimana warisan-warisan tersebut berwujud sumber daya alam tak terbatas yang terbentang di sepanjang pulau Jawa, dan untuk menjaga kelestarian warisan tersebut manusia harus bisa berdampingan saling menjaga alam yang diwariskan, ditegaskan dalam kalimat akhir epilog 'Sebagai titipan untuk peradaban selanjutnya di masa depan'.

Dalam penelitian sebelumnya yang dilakukan oleh Muhammad Aditya (2015), film Epic Java memiliki dampak dalam minat pariwisata di wilayah Jawa, khususnya pada berbagai lokasi yang digunakan untuk pengambilan gambar film Epic Java (Aditya, 2015). Ini menunjukkan bagaimana respon penonton dalam memaknai nilai kebangsaan dalam film. Visualisasi tentang kondisi geografis dan alam Indonesia yang luas dan indah membentuk kesan akan kealamian tanah Nusantara yang bagaikan negeri para dewadewa yang turun ke bumi. Hal inilah yang akhirnya mengakibatkan penonton film Epic
Java merasa untuk harus mengalami dengan mata sendiri bagaimana sebuah identitas kebangsaan yang tersebar di berbagai tempat itu.

Berbeda dengan Epic Java yang menggunakan prolog dan epilog sebagai titik awal dan akhir dari lingkup narasi film, Etanan memilih hanya menggunakan bahasa visual dalam membentuk keutuhan narasi. Obyek yang dipilih juga lebih mengerucut dan spesifik yaitu wilayah Tapal Kuda. Perbedaan beberapa aspek material dari kedua film tersebut akan mempengaruhi bagaimana masing-masing merumuskan wacana kebangsaan lewat sejumlah citra yang ditampilkan. Film Etanan juga tidak menjelaskan tentang rentang waktu narasi yang menjadi patokan bercerita seperti film Epic Java. Etanan hadir menjadi bentuk identitas kekinian atas kondisi kultural di wilayah Tapal Kuda.

Film Etanan hadir justru sebagai sebuah narasi kebangsaan yang lebih 'realistis', dalam artian tidak hanya tentang glorifikasi nasionalisme yang utopis, namun berani menampilkan bagaimana problem yang selalu menghantui negara ini. Selain menunjukkan visualisasi bagaimana kekuatan serta keunggulan bangsa, Etanan menampilkan berbagai ketimpangan sosial atau dampak dari tidak terkelolanya sumber daya alam yang melimpah, sehingga menyebabkan banyak permasalahan baru seperti pendidikan yang tidak merata, hasil pendidikan yang hanya digunakan untuk mendorong logika kapitalis industri, dan eksploitasi alam berlebihan. 
Genre association picture story memungkinkan untuk membentuk information linking di setiap gambar dan babak dalam film dokumenter. Keterkaitan antara gambar satu dengan gambar lainnya sehingga membentuk informasi dan makna baru membuat genre ini menjadi moda yang paling tepat untuk diaplikasikan dalam film Epic Java dan Etanan yang berbicara tentang ideologi kebangsaan. Wacana tentang nilai nasionalisme dalam film memang masih terbatas pada bagaimana nilai sebuah bangsa bisa diartikulasikan secara visual, dan yang paling sering digunakan adalah elemen fisik atau geografis dari Indonesia. Film dokumenter Epic Java dan Etanan menggambarkan nilai kebangsaan secara sistematik dan lengkap seolah dari 'hulu ke hilir'. Dimulai dari visual gunung, turun ke perbukitan hingga flora fauna yang ada di dalamnya, memasuki kehidupan masyarakatnya yang beragam dan kompleks, terus turun hingga garis pantai bahkan kehidupan di bawah laut. Indonesia yang memiliki sumber daya alam yang begitu luas membuatnya memiliki identitas sebagai negara tropis dengan alam yang indah. Genre association picture story membuat narasi ini menjadi sebuah kumpulan visual yang megah untuk menghidupkan kesan negara yang 'besar'.

\section{SIMPULAN}

Multimodalitas dalam genre association picture story telah mampu mengakomodasi bentuk narasi non-verbal dalam film dokumenter Epic Java dan Etanan. Dari aspek sinematografi serta bentuk bertuturnya, association picture story menjadi sebuah genre alternatif yang bisa mengikat berbagai elemen gambar untuk memproduksi sebuah wacana besar di dalam film.

Dalam setiap pembabakan narasinya, Epic Java dan Etanan melahirkan sebuah makna kebangsaan yang berbeda, yakni membicarakan tentang bagaimana bangsa yang memiliki keberagaman dan alam yang melimpah dapat hidup berdampingan membentuk hubungan dan interaksi yang harus dijaga.

Narasi kebangsaan dalam film Etanan memberikan sudut pandang baru dalam membongkar wacana tentang nasionalisme. Kemegahan alam dan keberagaman yang dimiliki Indonesia dihubungkan dengan narasi tentang dampak dari pengelolaan sumber daya yang kurang baik, membuat narasi kebangsaan menjadi utuh. Dalam arti ketika membahas ideologi kebangsaan, tidaklah terlepas dari segala permasalahan yang justru membuat nasionalisme itu menjadi lebih realistis.

Bentuk dari genre association picture story memungkinkan untuk dapat menyajikan data gambar dengan skema visual yang jauh lebih intens dibanding film dokumenter genre lainnya. Pendekatan riset serta data yang diartikulasikan secara visual akan lebih mampu diterima penonton dan dianggap mewakili realitas yang ada di lapangan. Inilah yang menyebabkan mengapa wacana kebangsaan 
dalam Epic Java dan Etanan dibentuk menggunakan genre association picture story, karena nilai kebangsaan akan lebih mudah diterima dalam bentuk narasi visual yang dapat diartikan secara bebas oleh setiap penontonnya. Pendekatan secara visual juga akan mengakomodir ideologi kebangsaan yang tidak bisa disajikan secara verbal.

\section{DAFTAR PUSTAKA}

Ablan, D. (2002). Digital Cinematography and Directing. New Riders Publishing.

Aditya, M. (2015). Pengaruh Film Epic Java terhadap Minat Wisata Komunitas CUT Film di Bandung. Telkom University.

Brown, B. (2012). Cinematography: Theory and Practice. New York: Focal Press.

Gaut, B. (2010). A Philosophy of Cinematic Art. Cambridge University Press.

Gianneti, L. (1995). Understanding Movies. Englewood Cliffs.
Kress, G., \& Leeuwen, T. Van. (2006). Reading Images: The Grammar of Visual Design (2nd ed.). London: Routledge.

Noviani, R. (2018). Wacana Multimodal menurut Gunther Kress dan Theo Van Leeuwen. In Hamparan Wacana. Yogyakarta: Ombak.

Saktinegara, F. N. (2013). Epic Java. Indonesia. Setiawan, I. (2017). Dokumenter TV: “Udjo \& Saung Angklung" Sebagai Manifestasi Budaya Sunda. ProTVF: Jurnal Kajian Televisi Dan Film, 1(1), 89-104.

Stam, R. (2005). New Vocabularies in Film Semiotics. London: Routledge.

\section{TAUTAN TERKAIT}

Trailer film dokumenter Epic Java: https://www.youtube.com/watch?v=LbbObG13 $\mathrm{hV4}$

Trailer film dokumenter Etanan: https://www.youtube.com/watch?v=e5QVMXq isd8 